\title{
First record of Coprophanaeus bellicosus (Olivier) (Coleoptera, Scarabaeidae) in a "Brejo de Altitude" forest in northeastern Brazil: a historical biogeographical approach
}

\author{
Fernando Augusto Barbosa Silva ${ }^{1}$ \\ ${ }^{1}$ Departamento de Entomologia, Universidade Federal de Lavras, Campus Universitário, 37200-000 Lavras-MG, Brasil. \\ fernandoabsilva@yahoo.com.br

\begin{abstract}
First record of Coprophanaeus bellicosus (Olivier) (Coleoptera, Scarabaeidae) in a "Brejo de Altitude" forest in northeastern Brazil: a historical biogeographical approach. This note presents the first record for a species of dung beetle of the genus Coprophanaeus, subgenus Megaphanaeus, in a "Brejo de Altitude" forest. Besides the new record, the paper discusses biogeographic aspects of the species and subgenus, as well as of the natural history of the "Brejos de Altitude", unique ecosystems in the northeast region of Brazil.
\end{abstract}

KEYWORDS. Atlantic Forest; dung beetle; geographic distribution.

RESUMO. Primeiro registro de Coprophanaeus bellicosus (Olivier) (Coleoptera, Scarabaeidae) em um Ecossistema de Brejo de Altitude na Região Nordeste do Brasil: uma abordagem biogeográfica histórica. Esta nota apresenta o primeiro registro para uma espécie de rola-bosta do gênero Coprophanaeus, subgênero Megaphanaeus, em um ecossistema de Brejo de Altitude. Além do novo registro, o trabalho enfoca e discute aspectos biogeográficos da espécie e subgênero, assim como da história natural dos Brejos de Altitude, ecossistemas exclusivos da região nordeste do Brasil.

PALAVRAS-CHAVE. Distribuição geográfica; Mata Atlântica; rola-bosta.

The Neotropical genus Coprophanaeus Olsoufieff 1924 was recently revised and includes 38 species distributed in three subgenera: Coprophanaeus s. str.; Metallophanaeus Olsoufieff and Megaphanaeus Olsoufieff (Edmonds \& Zídek 2010). According to Edmonds \& Zídek (2010), the subgenus Megaphanaeus is composed of four common species: $C$. bellicosus (Olivier, 1789), C. lancifer (Linné, 1767), C. ensifer (Germar, 1821) and C. bonariensis (Gory, 1844). Among the four species that compose the subgenus, the last three form the "lancifer" group, while C. bellicosus is isolated in a group that takes its name.

Species of Megaphanaeus occur throughout a large area of the South American continent. Using to the system of biogeographical provinces proposed by Morrone (2001) for Latin America and the Caribbean, the species of this subgenus are distributed, according to Edmonds \& Zídek (2010), in the following way: C. lancifer occurs exclusively in the Amazonian sub-region; $C$. ensifer in the Cerrado and Caatinga (xeric shrubland) of the Chacoan sub-region; $C$. bonariensis in the Cerrado and Chaco of the Chacoan sub-region and $C$. bellicosus in the Atlantic Forest of the southeast and south of Brazil, that makes up part of the Paranaian sub-region.

Among the species of Megaphanaeus, C. bellicosus is considered by Edmonds \& Zídek (2010) to be the most iso- lated in phylogenetic terms, and indeed was transferred, in 2002 by Arnaud, to the subgenus Coprophanaeus s. str. (Arnaud 2002)

Coprophanaeus bellicosus is under severe threat in parts of its distribution due to a history of severe habitat fragmentation from agricultural expansion and urbanization in the Atlantic forest region (Costa-Lima 1998). Until today, the most northern records of $C$. bellicosus in Brazil were in the municipal district of Entre Rios, in Bahia (Edmonds \& Zídek 2010). Here, I present the first record of C. bellicosus in a "Brejo de Altitude" ecosystem in the state of Pernambuco and I discuss biogeographic and evolutionary considerations implied by this new record.

Sixteen specimens of $C$. bellicosus were collected in forest areas of the Parque Ecológico João Vasconcelos Sobrinho $\left(8^{\circ} 18^{\prime} 36^{\prime \prime} \mathrm{S}, 36^{\circ} 00^{\prime} 00^{\prime \prime} \mathrm{W}\right)$, in the municipal district of Carua$\mathrm{ru}$, Pernambuco, Brazil. The individuals were captured in the months of November 2007 (2 individuals) and May 2008 (14 individuals), with the use of pitfall traps baited with bovine carcass (10 individuals) and flight intercept trap (6 individuals). The collection site consists of a "Brejo de Altitude" ecosystem inserted in a Caatinga Biome domain.

The "Brejo de Altitude" are humid areas, isolated in the semi-arid zones of the northeast interior (Andrade-Lima 1960, 
1961; Locatelli et al. 2004). These areas present distinct characteristics, such as: altitudes over $600 \mathrm{~m}$, humid or subhumid climate, annual precipitation between 900 and $1300 \mathrm{~mm}$, deep loamy soils, with a high level of available water, where redyellow podzolic soils and humic yellow-red latosols dominate (Jatobá 1989). These ecosystems present natural vegetation constituted by an evergreen or subperennial forest that covers the tops and the slopes of mountains, surrounded by xerophytic caatinga vegetation at the lower altitudes (Andrade-Lima 1960; Locatelli et al. 2004). Because of the humidity, there is a vegetation gradation, with the caatinga species being progressively substituted by deciduous forest (dry forest), until the emergence of the evergreen humid forest (Sales et al. 1998 apud Locatelli et al. 2004).

According to Morrone (2001), the Paranaian biogeographic sub-region, which encompasses the distribution of C. bellicosus is located in the northwest of Argentina, east of Paraguay, southern Brazil (west of the Serra do Mar to the middle of Rio Grande do Sul) and east of Brazil. As the "Brejos de Altitude" ecosystems are exclusive to the northeast region of Brazil and are inserted in the domain of the Caatinga, in the Chacoan sub-region, this new finding apparently represents a marked disparity from all previous records. However, Tabarelli \& Santos (2004) have suggested that a portion of the Brazilian Atlantic Forest is indeed comprised of the "Brejos de Altitude", with seasonal semi-deciduous montane forest.

According to Andrade-Lima (1982), the most accepted hypothesis for the origin of the "Brejos de Altitude" is associated with the climatic variations undergone during the Pleistocene, allowing the Atlantic Forest to penetrate into the domains of the Caatinga. When returning to its original distribution, after interglacial periods, islands of Atlantic Forest remained in areas with a favorable microclimate. Therefore, those islands of humid tropical forest within an otherwise semi-arid area are true "oasis", corridors where species of the Amazonian and Atlantic forest can appear, and the influence of isolated microclimates enables the presence of distinct species and subspecies.

In the literature we can find other studies that reinforce the hypothesis of Andrade-Lima (1982) for the origin and maintenance of the "Brejos de Altitude". For example, Santos (2002) studied the distribution pattern of Amazonian woody plants in twelve locations of the Northeastern Atlantic Forest. Santos' (2002) results suggest the preexistence of a forest corridor between the Amazonian and Atlantic forests. This forest corridor would be gradually separated with the retraction of the humid forest. Santos (2002) divided two great blocks of marshes that would be separated at the limits of the Pernambucan municipal districts: Brejo da Madre de Deus and Pesqueira. Besides that separation, a differentiation would also occur between the Atlantic Lowland Forest (on the coast) and the Atlantic Upland Forest (Forests in the interior of the state).

The presence of individuals of $C$. bellicosus in João Vasconcelos Sobrinho Ecological Park can be explained in the following way: a population that presented a wider distribution when the Atlantic forest was continuous area was fragmented during the retraction of the humid forest. Therefore, some typical elements of Atlantic forest, like $C$. bellicosus, were isolated in those "islands" of humid forest in the middle of the rural and semi-arid area of northeastern of Brazil. According to this hypothesis, and supported by the studies mentioned previously, the occurrence of that species in the "Brejo de Altitude" ecosystem is treated here as an example of a relictual population.

With this new record for $C$. bellicosus, we now know that a spatial overlapping exists in the distribution areas of two species of Megaphanaeus (C. bellicosus and $C$. ensifer) in the Atlantic forest of the Northeast. Besides the taxonomic revision of Edmonds \& Zídek (2010) pointing to a distribution area for $C$. ensifer that goes from the Cerrado, passing through the Caatinga and reaches the coast of the Northeast (Fig. 1), Endres et al. (2005) and Costa et al. (2009) registered individuals of this species in the Atlantic Forest of the Paraíba and Pernambuco coast, respectively. However, since according to Edmonds \& Zídek (2010), no case where two species of Megaphanaeus were collected together in a same habitat (ecological sympatry) has been verified until now, we believe that $C$. bellicosus can be restricted to higher areas of the Atlantic Forest of the northeast ("Brejos de Altitude"), while $C$. ensifer would occur at Atlantic Lowland Forest (northeastern coast).

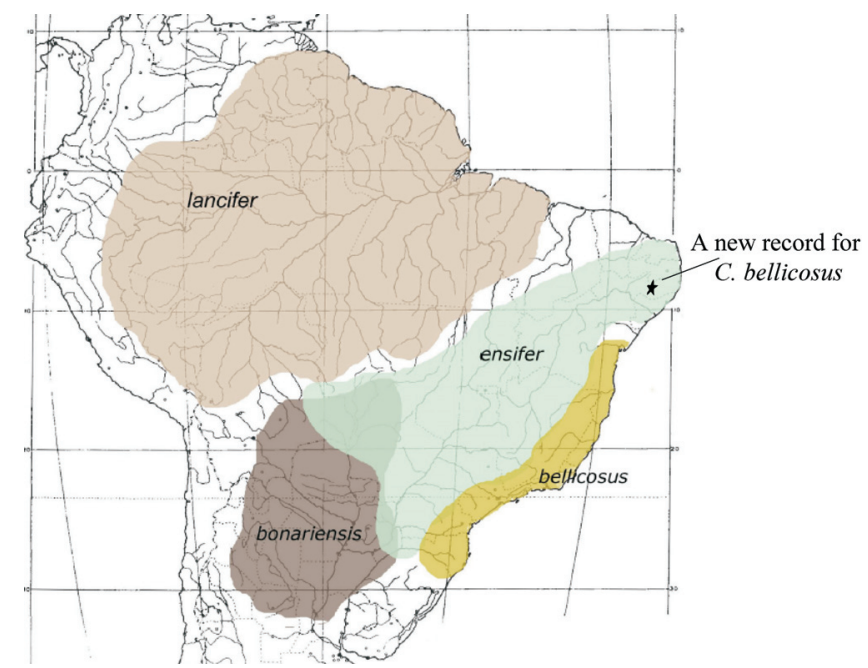

Fig. 1. Approximate geographic distribution of Coprophanaeus (Megaphanaeus) species and new record for Coprophanaeus bellicosus (modified from Edmonds \& Zídek 2010).

The specimens of $C$. bellicosus, collected in the present work and that of $C$. ensifer, captured by Costa et al. (2009), present another aspect worthy of drawing attention to. These individuals, in general, possess a smaller body size compared to those collected in other areas of Brazil. Edmonds \& Zídek (2010) affirm that the size range for the individuals of $C$. 
bellicosus can vary from 28 to $38 \mathrm{~mm}$. The average size of 16 individuals analyzed in Pernambuco is approximately 31 $\mathrm{mm}$, with an approximate range of 29 to $33 \mathrm{~mm}$. For C. ensifer, the authors mention a range of 30 to $56 \mathrm{~mm}$, while the average size of 11 individuals analyzed in Pernambuco is approximately $41 \mathrm{~mm}$, with a range between 36 and $47 \mathrm{~mm}$. However, other studies are necessary to verify any consistent differences in size patterns.

\section{ACKNOWLEDGEMENTS}

I thank Lívia D. Audino and Toby Gardner for the reading of, and suggestions for, the manuscript and Rita de Cássia de Moura for the sending of specimens for identification.

\section{REFERENCES}

Andrade-Lima, D. 1960. Estudos fitogeográficos de Pernambuco. Arquivo do Instituto de Pesquisas Agronômicas de Pernambuco 5: 305-341.

Andrade-Lima, D. 1961. Tipos de floresta de Pernambuco. Anais da Associação dos Geógrafos Brasileiros 2: 69-85.

Andrade-Lima, D. 1982. Present day forest refuges in Northeastern Brazil, p. 245-254. In: G. T. Prance (ed.). Biological Diversification in the Tropics. New York, Columbia University Press. 714 p.

Arnaud, P. 2002. Phanaeini. Les coléoptères du monde. vol. 28. Canterbury, Hillside Books, $151 \mathrm{p}$

Costa-Lima, M. L. F. 1998. A Reserva da Biosfera da Mata Atlântica em Pernambuco: situação atual, ações e perspectivas. Série Cadernos da Reserva da Biosfera, n. 12. São Paulo, Conselho Nacional da Reserva da Biosfera da Mata Atlântica. 44 p.

Costa, C. M. Q. da; F. A. B. Silva; A. I. de Farias \& R. de C. Moura. 2009. Diversidade de Scarabaeinae (Coleoptera, Scarabaeidae) coletados com armadilha de interceptação de vôo no Refúgio Ecológico Charles Darwin, Igarassu-PE, Brasil. Revista Brasileira de Entomologia 53: 88-94.

Edmonds, W. D. \& J. A. Zídek. 2010. A taxonomic review of the neotropical genus Coprophanaeus Olsoufieff, 1924 (Coleoptera: Scarabaeidae, Scarabaeinae). Insecta Mundi 0129: 1-111.

Endres, A. A.; M. I. M. Hernández \& A. J. Creão-Duarte. 2005. Considerações sobre Coprophanaeus ensifer (Germar) (Coleoptera, Scarabaeidae) em um remanescente de Mata Atlântica no Estado da Paraíba, Brasil. Revista Brasileira de Entomologia 49: 427-429.

Jatobá, L. 1989. Introdução à morfoclimatologia dos ambientes secos. Recife, UFPE. 75 p.

Locatelli, E.; I. C. Machado \& P. Medeiros. 2004. Riqueza de abelhas e a flora apícola em um fragmento da mata serrana (brejo de altitude) em Pernambuco, Nordeste do Brasil, p. 153-178. In: K. C. Pôrto; J. J. P. Cabral \& M. Tabarelli (Orgs.). Brejos de Altitude em Pernambuco e Paraíba. História Natural, Ecologia e Conservação. Brasília, Ministério do Meio Ambiente. 324 p.

Morrone, J. J. 2001. Biogeografia de América Latina y el Caribe. 3rd ed., Zaragoza, SEA. 148 p.

Santos, A. M. M. 2002. Distribuição de plantas lenhosas e relações históricas entre a floresta Amazônica, a floresta Atlântica costeira e os brejos de altitude do nordeste brasileiro. Dissertação de Mestrado, Recife, Universidade Federal de Pernambuco, 75 p.

Tabarelli, M. \& A. M. M. Santos. 2004. Uma breve descrição sobre a história natural dos brejos nordestinos, p. 17-24. In: K. C. Pôrto; J. J. P. Cabral \& M. Tabarelli (Orgs.). Brejos de Altitude em Pernambuco e Paraíba. História Natural, Ecologia e Conservação. Brasília, Ministério do Meio Ambiente. 324 p. 